\title{
A Proposal for the Constitution of a "Central Forestry Advisory Board".
}

Ferd otản.Bruyssel.

Porsong having vision and caring for Canada's wolfare all realize that more should be done for the preservation of the forest, considering its paramount importance in respect of climate, stream regulation and leading industries.

This is a question of national intorest, involving grave responsibility for the Dominion Government and those Provincial Governments having jurisdiction over forested Crown lands.

As a matter of course, there should be a centralization and co-ordination of conservative measures, concoivod, popularized and onforced with due rogard to commercial expoliency.

To such an end, a proposal was framed in the hopo that it might be considered at the recent Dominion-Provincisl Conference. But this was not done, the Agenda being full, and the time available relatively short; however, important members of the Conference subsequently expressed regret at having bsen unable to bring up the proposal for discussion, and suggested that it well might be followed up in conversation and correspondence.

The draft of the proposal and a full explanation thereof are here submitted for kind perusal, by members of the Society.

\section{The March of Forest Destruction.}

This is a relentless forced march which, having passed over the Northern States, is now proceeding into Canada.

When first projecting the Belgo-Canadian Mill, (Shawinigan Falls, Que.) in 1899, the writer had occasion to put on record that similar enterprises, originating in the United States, soon must follow the wood (also seek for water-power) across the line. The point here to be noted is that, a quarter of a century ago, American mills in quest of raw material did not have to reach out nearly as far afield in Canada, as Canadian mills must now range over their national territory for the same purpose.

Speaking of a quarter of a century ago, how striking the comparison between the price of pulp wood then and now even though due allowance be made for the present enhanced cost of labour and everything. In this connection, a pamphlet, for 
private circulation only, is available for whoever desires a fully corroborated description of forest \& paper mill conditions at the time.

Given the changes known to have occurred in forest conditions during the last twenty years, are these changes indicative of what is to be expected in the next similar period, with consumption largely increasing?

Commenting upon this subject, an important financier observed the other day: "Where are we going? To realize the actual position, one has only to look, as I did lately at the wood in the booms on the St. Maurice or at Fort Alfred; absurdly sma!l wood, comparatively to the logs of man-bearing size which we used to use".

With reference to the forest situation, this query: "Where are we going"? calls for quite an obvious and a really tragic answer, unless indeed some more potent remedy than any heretofore applied or contemplated be promptly brought into action. One knows that the same causes, particularly crude and wasteful methods of logging, which have wrought havoc in tho American forest, are largely operating here with equally disastrous results.

Something must be done to slow and possibly halt the march of Forest Destruction.

Any movement in this connection should bo led, ably and firmly, with proper regard for business and financial interests. A Central Forestry Board would be tho proper body to participate in its regulation.

The functions of such Board, acting in co-operation with official Forestry Services and with those of operating companies, may be outlined as follows:-

There is to be constant research, bearing upon the timber lands, to discover what silvicultural methods can be applied advantageously thereto. The aim is to find wherein profitable utilization is compatible with conservation.

Here, the initial difficulty to be faced is that a complete forest survey affords the only basis for determining the best working plans. Unfortunately, a forest survey, as distinguished from a mere reconnaissance, is a very expensive undertaking, quite within the province of government, but not generelly expedient for the private owner of pulp wood areas. He would have first to ascertain if the outlay could be compensated by results (possibly A/ cheaper logging under perfected working plans, 
B/ assured periodical yields). Where the Public Treasury derives a handsome revenue from the forest, government should be induced to spend more for conservation, in which cause forest survey is a factor, this is a question not to be overlooked.

However, there is no gainsaying that progress has been accomplished hero and there in the matter of forest surveys, growth estimates, cutting regulations and experiments in silvicultural methods. But much more of this is wanted, and there should be co-ordination in pritective measures to equalize amongst lumberers in all provinces whatever reasonable sacrifices may be required of them.

(2)

Meanwile, the legal cutting regulation generally consists in the fixation of a diameter limit. This selection system is properly applicable to composite stands such as those of wild forest in this country. But the diameter limit is not determined, as it should be, after trial computations of the rate of growth, comparing assumed cuts to 10 , to 12 and to 14 inches respectively (d.b.h), in the case of white spruce.

Another question to be attended to for conservation is the enforcement of whatever diameter limit regulation has been determined. In practice, but perticularly where logging is done by contractors, no such enforcement is controllable, unless the troes to be felled are previously marked, with a blaze breast high and with a check-blaze, also a stamp, below the point where the stump-cut will be made. Marking offers obvious advantages apart from conservation; still it is, under the best conditions, a source of expense which should be woighed properly from the standpoint of true economy.

Everybody knows that the fire danger is intensilied by logging under the selection system, this being on account of the slash, which is too costly in removal from the remaining stand to a sale place of burning. The recognized corrective consists in lopping the tops and scattering the brush. Such work, which must be looked after in the interest of conservation, is not unreasonably onerous; at any rate, the outlay is an inperative sacrifice to be incurred for the sake of comparative safety. This outlay is to be calculated in relation, not to the area covered, but to the amount of timber cut, measured in board feot.

Referring with slightly more detail to the matters broached in clause 1 above, watch is to be kept over ground where no detailed survey is required for indicating the advisability of applying some silvicultural system apart from selection. On exposed slopes, for instance, matured coniferous stands may not 
be thinned heavily without aausing ruin through windfalls, Clear cutting is thero compulsory, with proper precautions (prompt seeding or planting) against subsequent erosion.

In Eastern Canada, the interior of British Columbia (outside of the dry belt) and possibly elsewhere, conservation investigators should incline favourably to clear cutting (wholly, in strips, or in patches) where brudh disposal is greatly facilita.ted and reproduction, when successful, follows in uniform stands. But, further experimentation by government and large operators is required to establish if the recognized failings of this system can be overcome, and particularly if there can be conditions where reproduction (natural or aided by artificial seeding) is not checked by soil dessication, grass or weeds. This great disadvantage, also to be expected under the shelter-wood system, may be lessened if cutting be coincident with a seed year.

(6)

Discreet propaganda is to be directed towards bringing into effect a proper classification of Crown lands, whether suited for agriculture, or better left to the forest, even if arable, where stream regulation is involved. On the basis of such classification, forest reserves, open of course, to private exploitation as heretofore, should be instituted by law - not by Order-in-Council, subject to constant amenjusnt under political pressure for encroachment. It is needless here to dwoll upon the activities of the "timber pirate", nor upon the tribulations of the bona fide settler upon poor and shallow land.

Measures of fire and insect protection are certainly within the scope of a Central Forestry Board, insofar as not provided for.

(8)

The immediate effect, although perhaps not the after results, of restricting the annual cut, would naturally bo felt more by small than by large holders. Nevertheless both, it is needless to say, aro deeply interested in the question. Without having had occasion, as yet, to make any direct enquiries in Ontario, the writer has been told that officially, in Quebec, there is an actual intention in some cases already put into practice - of resorting to a restrictive measure, based upon some conception of periodic increment in volume. On this point, a satisfactory understanding with the authorities must be sought, if it does not exist already. The increment in volume can only be determined more or less arbitrarily, given a provious analysis of the forest, and a proper classification as to diameter and thriftiness of the small trees to be left after cutting. In our wild forest, there is seldom such a thing as net growth; decay and growth generally balance, except in stands of immature, even-aged 
spruce. Even so, black spruce boing very sound and its growth very slow, both growth and decay are practically nil during whatover rotation has been adopted.

Aside from what has been said of protection (under clause 7) the most important care, vested in the proposed Board, rests with the regeneration of cut-over tracts.

Some, of course, are in a hopeless state; fire has 6 eaten deeply into the soil, there remains neither shelter nor seed trees. Hence, recuperation in slow stages must be left to nature, unless planting can be done at some time by Government.

A question arising here is whether it be worth while (for instance, in view of the eventual exclusion of other operators) to continue paying ground-rent on such lots? May not, in good economy, the same question apply to all the poorer areas which, having been exploited once or several times on any company's holdings, offer no prospects of future cuttings, nor a sufficiently early reclamation?

Regarding lots which may be in a fair way of natural recovery, it is to be considered if business interest calls for the company concerned to intervene for accelerating such recovery, by means of artificial seeding, clearing of weed trees and brush?

But as to artificial reproduction by planting, the attendant cost, reckoned at compound interest up to a remote day of harvest, is too great for the commercial operator, unless perhaps it be in such exceptional case as the following: indeed, one can conceive that on land bought very cheaply in fee simple, and proximate to a paper mill, the expenditure for planting may be compensated in due course by the elimination of stumping and driving charges, besides the minimizing of the cost of transportation.

Be this as may be, the rule is that, on Crown lands artificial reproduction should be undertaken vholly - or, in exceptional cases, perhaps only partially - by Government, whose present supineness regarding this public duty is to be combated. But, with proper care, of course, not to incur any measure of official resentment.

Forest Research - Conversation with Dominion and Provincial foresters reveals an absence of correlation in forest research programmes throughoút Eastern Canada. Should a Central Forestry Board be appointed, it would be able to $r$ ecord the conditions under which all notable silvicultural experiments are made, and also to co-ordinate their results, to such effect that a basis 
of knowledge for the best treatment of our coniferous or composite forests may be obtained. It stands to reason that holders of forest land must hesitate to innovate, whether in exploitation or in fostering natural forestation, until demonstrated methods give reasonable promise of success and profit.

Should the reader's interest in the question itself have induced him to follow this letter throughout, I trust that he will have acquired the conviction, had he not it before, that prompt action should be taken to intensify and unify policies to save the forest.

Wherefore, I beg earnestly that the reader will be pleased to use his influence in order that the principle at least be accepted of the proposal set forth in the preliminary draft herewith - details might well be agreed upon subsequently through correspondence.

\section{Preliminary Draft for Constitution of} A Centrel Forestry Board.

1. The Board to be appointed by the Dominion and composed as follows:-

Members to be chosen by the Dominion.

Members to be designated by each of the provinces havin $n_{0}$ a Forestry Service and consenting to be represented on the Board; and preferably but not essentially; members, one of which may bo designated by the Canadian Forestry Association, one by the Canadian Pulp and Paper Association and one by any one recognized lumbermen's or limit holders association within each province represented on the Board.

Members of the Board chosen by the Dominion and the provinces having Forest Services, should be technically trained foresters.

2. The Board elects yearly a chairman and vice chairman to hold office during the succeeding year; they are to be re-eligible.

3. The Board to appoint a salaried executive officer who, under the qualification of Commissioner, is to be concerned and occupied, to the exclusion of any other remunerated employment, in pursuing the Board's activities and policies as he may be directed.

4. The Board to meet twice yearly (on the first Tuesday in June and February respectively) and also, whenever a 
special meeting is called by the chairman.

5. Members to receive (from the Board's appropriation) a fee of.......on attending each meeting; travelling expenses of members to be met by the government or corporate body they represent respectively.

6. A yearly appropriation of $\$ \ldots . . .$. for the purposes of the Board is to be provided as follows:- $1 / 3$ by the Dominion, $2 / 3$ by the provinces and corporate bodies represented on the Board, their respective contribution reckoned on such basis that, the whole contributed amount being divided into as many equal parts as there are provincial and corporate appointed members of the Board, each contributor will pay one of such parts for each appointed representative he may have on the Board.

7. The purposes of the Board to be as follows:The instigation and direction of experimentation and research, bearing upon our variously situated timber lands, to discover what silvicultural methods can be applied advantageously for their proper exploitation and, at the same time, their preservation.

2.

To co-ordinate all such work, so that there will be as little overlapping of effort and financial expenditure as possible.

3. Research directed to discovery of perfected means for combating forest fires and noxious insects.

4. Research for best economic means of promoting both natural and artificial forest regeneration; co-ordination and analysis of results obtained in experimentation to such purpose at home and abroad.

5. Maintenance of active relations with: (a) chemists and entomologists for the solution of problems; (b) foresters, both official (federal and provincial) or private, to influence them in whatever may benefit the cause of conservation and for mutual information. This would establish a needed liaison between scientists and foresters, and between foresters themselves, and would stimulate them to further effort in research and in application.

6. A study of methods and market conditions that would lead to the greater utilization of the so-called inferior woods, and by products of the lumber and paper industries. 